\title{
Sperm distribution in the oviduct and uterus of mares within two hours after artificial insemination
}

\author{
Sandra M. Fiala', Maria Ines M. Jobim², Terttu Katila3, Ricardo M. Gregory² and Rodrigo C. Mattos² \\ Departamento Morfologia, Instituto de Biologia-UFPel, Pelotas-RS'1, REPROLAB, Departamento Medicina Animal, Faculdade de Veterinária-UFRGS, \\ Porto Alegre - RS² and Department of Production Animal Medicine, University of Helsinky, Finland ${ }^{3}$
}

\begin{abstract}
Summary
Our objective was to determine the sperm distribution in the uterus and the number of sperm cells that reach the oviducts after $0.5,1,1.5$ and $2 \mathrm{~h}$ of artificial insemination (Al). Thirty mares with a dominant follicle $>35 \mathrm{~mm}$ in diameter and no bacterial growth or neutrophils detected in uterine smears were inseminated with a total dose of $500 \times 10^{6}$ cooled sperm $\left(25 \times 10^{6} \mathrm{ml}-1\right.$ spermatozoa diluted in skim milk) stored at $4^{\circ} \mathrm{C}$ for 18 to $22 \mathrm{~h}$ until use. The mares were slaughtered $0.5(\mathrm{n}=3), 1(\mathrm{n}=10) 1.5(\mathrm{n}=4)$ or $2 \mathrm{~h}(\mathrm{n}=13)$ after Al. The oviducts were separated from the uterus and flushed with phosphate-buffered saline. Spermatozoa were detected in oviduct flushes from $0.5 \mathrm{~h}$ onwards after Al and sperm cells were observed in flushes from oviducts in $66.7 \%$ of the mares regardless the time of Al. No differences were observed either in the number of sperm cells between the groups or in the number of mares with sperm cells in the oviducts. No differences were observed in the number of mares presenting spermatozoa in the oviduct ipsilateral to the dominant follicle when compared with the contralateral oviduct or in the number of spermatozoa that reached the tubes. Sperm cells were found in the uterus by histological examination in $88.8 \%$ of the mares slaughtered $1 \mathrm{~h}$ after $\mathrm{Al}$ and spermatozoa were located in the uterine glands in $70 \%$ of the mares. It can be concluded that sperm cells reach the tube already $0.5 \mathrm{~h}$ of insemination. The uterine glands are a possible reservoir for spermatozoa in addition to the oviductal isthmus and the uterotubal junction.
\end{abstract}

Keywords: artificial insemination, mare, sperm transport, oviduct, uterus, reproduction

\section{Verteilung der Spermien in Eileiter und Uterus in den ersten zwei Stunden nach künstlicher Besamung}

Ziel der Arbeit war die Bestimmung der Spermienverteilung im Uterus und die Ermittlung der Anzahl derjenigen Spermien, die den Eileiter innerhalb von 30, 60, 90 und 120 min nach instrumenteller Samenübertragung erreichen. Zum Einsatz kamen 30 Stuten ohne Nachweis von neutrophilen Granulozyten im Endometriumausstrich und kulturellem Bakteriumwachstum aus der Tupferprobe. Die Insemination erfolgte, sobald ein dominanter Follikel (>35mm im Durchmesser) vorlag mit einer Gesamtanzahl von 500 x $10^{6}$ gekühlten Spermien $\left(25 \times 10^{6} \mathrm{ml}-1\right.$ Spermatozoen in Magermilchverdünner), die vor Gebrauch für 18 bis 22 Stunden bei $4^{\circ} \mathrm{C}$ gelagert worden waren. Die Stuten wurden $30 \mathrm{~min}(\mathrm{n}=3), 60 \mathrm{~min}(\mathrm{n}=10), 90 \mathrm{~min}(\mathrm{n}=4)$ und $120 \mathrm{~min}(\mathrm{n}=13)$ nach Insemination geschlachtet. Die Eileiter wurden vom Uterus abgetrennt und mit Phosphatpuffer gespült. Spermatozoen konnten in Eileiterspülproben ab 30 min nach Insemination nachgewiesen werden. Unabhängig vom Zeitpunkt der Insemination wurden in 66,7\% der Proben Spermien ermittelt. Es bestanden keine Unterschiede bezüglich der Spermienanzahl innerhalb der Gruppen, der Anzahl der Stuten, in deren Eileiter Spermien gefunden werden konnten, der Anzahl der Spermien in den zum dominanten Follikel ipsilateralen Ovidukt, verglichen mit dem kontralateralen Organ, oder der Anzahl derjenigen Spermien, die den Eileiter erreicht hatten. In 88,8\% der Stuten, die eine Stunde nach Insemination geschlachtet worden waren, konnten histologisch Spermien im Uterus nachgewiesen werden, zu 70\% waren sie innerhalb der Uterindrüsen lokalisiert. Zusammenfassend wird festgestellt, dass Spermien bereits innerhalb von 30 min die Eileiter erreichen. Die Uterindrüsen dienen möglicherweise als Reservoir für Spermien, zusätzlich zum Eileiteristhmus und dem uterotubalen Verbindungsstück.

Schlüsselwörter: instrumentelle Samenübertragung, Pferd, Spermientransport, Eileiter, Uterus, Reproduktion

\section{Introduction}

Spermatozoa are deposited directly into the uterus of the mare during mating or artificial insemination (Al). Frequent uterine contractions after Al carry sperm back and forth between the uterine body and the horn tips (Katila et al. 2000). It is very likely that some of these sperm gain access to the oviducts very soon after $\mathrm{Al}$, but the time of the first appearance of sperm in the oviducts of the mare has not been documented. Within $1 \mathrm{~h}$ after breeding, seminal compounds were found in the oviduct of the mare (Mann et al. 1956) and sperm were detected in the oviducts $2 \mathrm{~h}$ after insemination with fresh or frozen-thawed semen (Bader 1982). Large numbers of sperms were present in the oviducts $4 \mathrm{~h}$ after insemination, but there was a reduction in the number of sperms recovered from the oviducts $6 \mathrm{~h}$ after insemination (Bader and Krause 1980). These observations suggest a gradual elimination of sperms from the oviduct and the cessation of further sperm transport through the uterus (Bader 1982). Pregnancy rates were significantly lowered when mares were flushed within $2 \mathrm{~h}$ after $\mathrm{Al}$, but uterine lavage performed at 4 $\mathrm{h}$ had no adverse effect on fertility (Brinsko et al. 1990 and 1991).

Sperm reservoirs are sites within the female tract that accumulate and maintain a population of viable spermatozoa for an extended period. An intimate contact of sperm with the luminal epithelium in those locations is regarded as important for maintenance of sperm viability and function (Smith and 
Yanagimachi 1990). After breeding, spermatozoa from the different mammals are transported through the uterus, forming a sperm reservoir in the uterotubal junction (UTJ) and the adjacent 1-2 cm of the isthmus (Viring 1980, RodríguezMartínez 2001, Brandt et al. 2004, Chatdarong et al. 2004, Rijsselaere et al. 2004, Steinhaver et al 2004, Suarez and Pacey 2006). In the cat and the bitch, the uterine glands were described as a sperm reservoir before ovulation (Chatdarong et al. 2004, Rijsselaere et al. 2004). In the mare, during the preovulatory period, the oviductal isthmus (Thomas et al. 1994) and the uterotubal junction (Scott et al. 2002) have been suggested as sperm reservoirs.

This study aimed to examine sperm distribution in the uterus and to determine the earliest time of the entrance of spermatozoa into the oviducts. Also the numbers of sperm cells that will reach the oviducts after $0.5,1,1.5$ and $2 \mathrm{~h}$ of $\mathrm{Al}$ with cooled stored semen were determined.

\section{Materials and methods}

Animals

Thirty mixed-breed mares in estrus were selected from a population of horses sent to slaughter in an abattoir located at parallel 32o south in southern Brazil. Semen was collected from a fertile stallion that was housed $20 \mathrm{~km}$ from the abattoir.

\section{Clinical examinations and insemination}

Candidate mares were examined for reproductive soundness and only clinically normal mares with negative cytology (absence of PMNs) and negative cultures (no growth or insignificant contaminant isolates) were used in this study. Soon after collection using an artificial vagina, semen was diluted in skim milk (Molico, Nestlé, São Paulo, Brazil) to $25 \times 10^{6} \mathrm{ml}^{-1}$. The $\mathrm{Al}$ volume was $20 \mathrm{ml}$ and sperm numbers $500 \times 10^{6}$. Semen was kept in a cooling transport container (Equitainer, Hamilton Research Inc., Hamilton, MA, USA) at 4 ${ }^{\circ} \mathrm{C}$ for 18 to $22 \mathrm{~h}$ until its use.

\section{Experimental procedures}

Mares were slaughtered $0.5(n=3), 1(n=10) 1.5(n=4)$ or $2 \mathrm{~h}(\mathrm{n}=13)$ after $\mathrm{Al}$. Internal reproductive tracts were recovered within 10 min after slaughter. The uterus was sectioned and a portion from uterine body, each horn and each uterotubal junction (UTJ) was obtained after macroscopic examination. The samples were fixed in Bouin's solution and processed for histological examination. The slides were stained with hematoxylin-eosin and analyzed under a light microscope (400x). The slides were evaluated for spermatozoa in the luminal epithelium, uterine glands and UTJ.

Oviducts were separated from the uterus, placed in a dish and flushed with $1 \mathrm{ml}$ phosphate-buffered saline (PBS) from the infundibulum toward the isthmus. The flush was stirred and a sample $(50 \mu \mathrm{l})$ of each tubal flushing was placed in a Neubaver chamber. Each sperm counted in the chamber represented $5 \mathrm{sperm} / \mathrm{mm}^{3}$.

\section{Statistical analysis}

To normalize the data, the number of sperm cells in flushes was transformed to $\log 10(y+10)$. Data were analyzed using ANOVA. Numbers of spermatozoa in the flushes of the oviducts were considered as dependent variables and time before artificial insemination as independent variable. The Tukey's test was used to compare the means. The number of mares with and without sperm cells in the oviducts was evaluated by Chi-Square analysis. Values were considered to be statistically significant at $\mathrm{P}<0.05$.

\section{Results}

Spermatozoa were detected in oviductal flushes at $0.5 \mathrm{~h}$ after insemination. Differences between groups were observed neither in the number of sperm cells $(P=0.27)$ flushed nor in the number of mares with sperm cells in the oviducts ( $P=$ 0.26) (Table 1). Sperm cells were observed in flushes from

Table 1 The number and percentage of mares presenting sperm cells in the oviducts and mean and standard deviation of sperm cells flushed from the oviducts $0.5,1,1.5$ and $2 \mathrm{~h}$ after artificial insemination (Al).

Anzahl und prozentuale Häufigkeit derienigen Stuten, bei denen Spermien in den Eileitern nachgewiesen werden konnten, und Mittelwert mit Standardabweichung der Spermien in Eileiterspülproben 30, 60, 90 und 120 min nach Insemination.

\begin{tabular}{lccc}
\hline \multirow{2}{*}{$\begin{array}{l}\text { Time } \\
\text { after Al }\end{array}$} & $\mathrm{n}$ & $\begin{array}{c}\text { Mares } \\
\text { (\%) with }\end{array}$ & $\begin{array}{c}\text { Sperm cells [log } \\
\text { sperm } \\
(\mathbf{y}+10)] \\
\text { Mean } \pm \text { SD }\end{array}$ \\
\hline $0.5 \mathrm{~h}$ & 3 & $2^{\mathrm{a}}(66.6)$ & $3.05^{\mathrm{b}} \pm 1.82$ \\
$1.0 \mathrm{~h}$ & 10 & $8^{\mathrm{a}}(80.0)$ & $3.69^{\mathrm{b}} \pm 1.46$ \\
$1.5 \mathrm{~h}$ & 4 & $1^{\mathrm{a}}(25.0)$ & $1.79^{\mathrm{b}} \pm 1.58$ \\
$2.0 \mathrm{~h}$ & 10 & $7^{\mathrm{a}}(70.0)$ & $3.32^{\mathrm{b}} \pm 1.64$ \\
\hline
\end{tabular}

$x^{2}=3.975 ; P=0.26$, values with common subscript letter (a) represent no significant difference. Values with a common subscript letter (b) represent no significant difference $(P=0.27)$.

Table 2 The number and percentage of ipsi- and contralateral oviducts presenting sperm cells and mean and standard deviation of sperm cells flushed from the oviducts after artificial insemination. Anzahl und prozentuale Häufigkeit von zum dominanten Follikel ipsiund kontralateralen Eileitern, in denen Spermien gefunden wurden, und Mittelwert mit Standardabweichung der Spermien in der Eileiterspülprobe nach Insemination.

\begin{tabular}{|c|c|c|c|c|}
\hline \multirow[t]{2}{*}{ Oviduct } & \multirow{2}{*}{$\begin{array}{c}\text { Total } \\
n\end{array}$} & \multicolumn{2}{|c|}{ with sperm } & \multirow{2}{*}{$\begin{array}{c}\text { Sperm cells [log } \\
(y+10)] \\
\text { Mean } \pm \text { SD }\end{array}$} \\
\hline & & $n$ & $\%$ & \\
\hline Ipsilateral & 27 & $14^{a}$ & 51.8 & $4.26^{b} \pm 0.40$ \\
\hline Contralateral & 27 & $11^{\circ}$ & 40.7 & $4.10^{b} \pm 0.29$ \\
\hline
\end{tabular}

oviducts in $66.7 \%$ of the mares regardless the insemination moment. No differences were observed in the number of mares presenting sperm cells $(P=0.41)$ in the oviduct ipsilateral to the dominant follicle when compared with the contralateral oviduct or in the numbers of spermatozoa that reached $(P=0.27)$ the tubes (Table 2$)$. Sperm cells were observed in the uterus by histological examination in $88.8 \%$ and $76.9 \%$ of the mares slaughtered 1 and $2 \mathrm{~h}$ after insemination, respectively. One or two hours after $\mathrm{Al}$, spermatozoa were 
located in just a few uterine glands, without PMN's presence in $70 \%$ and $61.5 \%$ of the mares, respectively.

\section{Discussion}

This study demonstrated the presence of spermatozoa in the oviducts already $0.5 \mathrm{~h}$ after $\mathrm{Al}$. It is possible that the spermatozoa enter the oviducts even earlier as in the swine (Baker and Degen 1972), but we did not have the possibility to examine mares immediately after Al.

In the present report, the number of sperm cells observed $2 \mathrm{~h}$ after $\mathrm{Al}$ in the oviducts and at the UTJ junction was similar to the observation by Fiala et al. (2007) using the same sperm concentration and the same examination time after insemination.

The number of sperm cells delivered into the tubes was similar within 0.5 and $2 \mathrm{~h}$ after insemination. The number of mares with spermatozoa and the sperm population observed into the contra- and ipsilateral tubes of the dominant follicle were similar in the first two hours after insemination. These findings demonstrate that probably a first wave of sperm transport occurred immediately after seminal deposition aided by contractions of the myometrium associated with $\mathrm{Al}$ (Katila et al. 2000). Sperm cells seem to be directed independently of a hormonal guidance or a thermotaxis effect (Bahat and Eisenbach 2006). It is possible that this wave is responsible for the sperm population in the reservoirs in addition to the presence of the first spermatozoa in the oviducts.

The mares used in this study were clinically normal but their reproductive history was unknown. Spermatozoa were detected in more than $66 \%$ of the mares. Probably the mares without sperm cells in the oviducts can belong to a subfertile group, with impaired uterine contractility and sperm transport.

Spermatozoa were located in uterine glands $1 \mathrm{~h}$ after the insemination. Maybe also in the mare, the uterine glands can act as sperm reservoirs like the oviductal isthmus (Thomas et al. 1994) and the uterotubal junction (Scott et al. 2002). In the queen, the UTJ and the uterine crypts acted as sperm reservoirs before ovulation whereas the isthmus was a sperm reservoir around the time of ovulation (Chatdarong et al. 2004). In the bitch, histology revealed that the spermatozoa were mainly located in the uterine glands and at the UTJ, while very few spermatozoa were detected in the uterine tube. The uterine glands and the UTJ might act as sperm reservoirs in the bitch and sperm transport in the genital tract is affected by the time of $\mathrm{Al}$ in relation to ovulation. They may also play an important role as an initial selection mechanism for the spermatozoa that will reach the fertilization site (Rijsselaere et al. 2004).

It is concluded that in the mare sperm cells reach the oviductal tubes 30 minutes after semen deposition. The uterine glands are a possible reservoir for spermatozoa like the oviductal isthmus and the uterotubal junction.

\section{Literature}

Bahat A. and M. Eisenbach (2006) Sperm thermotaxis. Mol. Cell. Endocrinol. 27,115-119
Baker R. D. and A. A. Degen (1972) Transport of live and dead boar spermatozoa within the reproductive tract of gilts. J. Reprod. Fertil. 28, 369-377

Bader H. (1982) An investigation of sperm migration into the oviducts of the mare. J. Reprod. Fertil. 32, 59-64

Bader H. and A. Krause (1980) Investigations about the transport, distribution and the fate of the spermatozoa in the genital tract of the mare. In: Proceedings of Ninth International Congress on Animal Reproduction Al, vol. 5; 197-205

Brandt Y., A. Lang, H. Rodriguez-Martinez, A. Madej and S. Einarsson (2004) Impact of ACTH during oestrus on the ultrastructure of the spermatozoa and their environment in the tubal reservoir of the postovulatory sow. Reproduction 128, 801-811

Brinsko S. P., D. D.Varner, T. L. Blanchard and S. A. Meyers (1990) The effect of post-breeding uterine lavage on pregnancy rate in mares. Theriogenology 33, 465-475

Brinsko S. P., D. D Varner and T. L Blanchard (1991) The effect of uterine lavage performed four hours post insemination on pregnancy rates in mares. Theriogenology 35, 1111-1119

Chatdarong K., C. Lohachit and C. Linde-Forsberg (2004) Distribution of spermatozoa in the female reproductive tract of the domestic cat in relation to ovulation induced by natural mating. Theriogenology 62, 1027-1041

Fiala S. M., C. A. Pimentel, A. L. G. Mattos, R. M. Gregory and R. C. Mattos (2007) Effect of sperm numbers and concentration on sperm transport and uterine inflammatory response in the mare, Theriogenology 67, 556-562

Katila T., Sankari S. and Mäkelä O. (2000) Transport of spermatozoa in the reproductive tracts of mares. J. Reprod. Fert., Suppl. 56, 571-578.

Mann T., C. Polge and L. E. A. Rowson (1956) Participation of seminal plasma during the passage of spermatozoa in the female reproductive tract of the pig and horse. J. Endocr. 13, 133-140

Rijsselaere T., A. Van Soom, S. Van Cruchtenv, M. Coryn, K. Görtz, D. Maes and A. de Kruif (2004) Sperm distribution in the genital tract of the bitch following artificial insemination in relation to the time of ovulation. Reproduction 128, 801-811

Rodriguez-Martinez H. (2001) Oviduct function in cows and pigs: with special reference to sperm capacitation. Asian Aust. J. Anim. Sci. 14 (special issue), 28-37

Scott M. A., D. D. Varner, I. K. M. Liu and A. C. Enders (2002) Presumptive evidence of a preovulatory sperm reservoir in the mare: morphological investigations using scanning electron microscopy. Theriogenology 58, 639-642

Smith T. T. and Yanagimachi R. (1990) The viability of hamster spermatozoa stored in the isthmus of the oviduct: the importance of sperm-epithelium contact for sperm survival. Biol. Reprod. 42, 450-457

Steinhaver N., A. Boos and A. R. Günzel-Apel (2004) Morphological changes and proliferative activity in the oviductal epithelium during hormonally defined stages of the oestrous cycle in the bitch. Reprod. Dom. Anim. 39, 110-119

Suarez S. S. and A. A. Pacey (2006) Sperm transport in the female reproductive tract. Hum Reprod. Update 12, 23-37

Thomas P. G, B. A. Ball, P. G. Miller, S. P. Brinsko and L. Southwood (1994) A subpopulation of morphologically normal, motile spermatozoa attach to equine oviductal epithelial cell monolayers. Biol. Reprod. 51, 303-309

Viring S. (1980) Distribution of live and dead spermatozoa in the genital tract of gilts at different times after insemination. Acta Vet. Scand.21, 587-97

Dr. Sandra Fiala
Departamento Morfologia
Instituto de Biologia-UFPel
Pelotas-RS
Brazil
sandrafiala@yahoo.com.br

Dr. Sandra Fiala

Departamento Morfologia

Pelotas-RS

sandrafiala@yahoo.com.br 